\title{
HUBUNGAN SIKAP TERHADAP PRESTASI BELAJAR BAHASA INDONESIA SISWA KELAS II SMP NEGERI 3 BATU LEPPA KECAMATAN SINJAI SELATAN KABUPATEN SINJAI
}

\author{
Iskandar \\ Fakultas Keguruan dan Ilmu Pendidikan Universitas Muhammadiyah Makassar \\ iskandar@gmail.com
}

\begin{abstract}
ABSTRAK
Tujuan yang ingin dicapai dalam penelitian ini adalah mendeskripsikan hubungan sikap terhadap prestasi belajar bahasa Indonesia siswa kelas II SMP Negeri 3 Batu Lappa Kecamatan Sinjai Selatan Kabupaten Sinjai. Untuk mendapatkan data yang akurat,maka proses penelitian ini dirancang sedemikian rupa sehingga Hal-hal yang tidak berhubungan dengan tujuan penelitian dapat dihindari.Oleh karena itu, kegiatan penelitian ini melalui beberapa tahap pertama yaitu diadakan tinjauan kesekolah tempat penelitian untuk mengamati situasi dan kondisi sekolah tersebut termasuk waktu yaitu tahap penyusunan proposal penelian termasuk instrumen yang akan dipergunakan untuk menjaring data termasuk surat izn penelitian dari pihak terkait. Hasil penelitian ini menunjukkan bahwa ada hubungan sikap terhadap prestasi belajar bahasa indonesia siswa kelas II SMP Negeri 3 Batu leppa kecamtan sinjai selatan kabupaten sinjai. Hal ini dibuktikan bahwa r-hitung $(0,884)$ lebih besar dari pada $r$ - tabel $(0,22)$. Jadi hipotesis alternatif (hipotesis penelitian ) diterimah. Berdasarkan hasil penelitian ini, perlu diserahkan kepada guru, khususnya guru bahasa dan sastra indonesia kelas II SMP Negeri 3 Batu leppa kecamatan sinjai selatan kabupaten sinjai agar lebih meningkatkan kemampuan mengajar
\end{abstract}

Kata Kunci: Sikap, prestasi belajar, bahasa indonesia dan siswa

\section{ABSTRACT}

The goal of this research is to describe the relationship attitude towards learning achievement of Indonesian students in grade II SMP Negeri 3 Batu Lappa Southern Sinjai Sinjai district. To obtain accurate data, the research process is designed so that things that are not related to the research objectives can be avoided. Therefore, this research activity through the first few stages are held for school reviews a study to observe the situation and condition of these schools include the time that drafting stage research proposal includes instruments that will be used to collect data including letters izn research from related parties. The results of this study indicate that there is a relationship attitude towards learning achievement of Indonesian students in grade II SMP Negeri 3 Batu leppa southern districts Sinjai Sinjai district. It was proven that r-count (0.884) is greater than the $r$ - table (0.22). So the alternative hypothesis (hypothesis) are acceptable. Based on these results, it should be handed over to the teachers, especially teachers of language and literature class II Indonesia SMP Negeri 3 Batu leppa south district Sinjai Sinjai districts to improve their teaching skills

Keywords: attitude, academic achievement, Indonesian and students

\section{PENDAHULUAN}

Pendidikan yang berkualitas adalah cermin bangsa dalam menciptakan pemimpin penerus yang akan mewarisi estapet kepemimpinan di masa yang akan datang. Pendidikan yang berkualitas tersebut tentu tidak hanya dapat dicapai dengan mengandalkan modal, tetapi memerlukan perjuangan yang cukup lama dan ketabahan bagi individu yang menuntut, setidak-tidaknya dinilai dari pendidikan Sekolah Dasar sampai pada tingkat pendidikan yang lebih tinggi.

Bahasa Indonesia merupakan salah satu mata pelajaran yang diberikan kepada siswa mulai dari pendidikan Sekolah Dasar sampai pada tingkat pendidikan yang lebih tinggi karena bahasa Indonesia menjadi dasar untuk mendapatkan Ilmu pengetahuan dalam bidang pendidikan apapun sehingga prestasi belajar bahasa Indonesia perlu ditingkatkan. 
Prestasi belajar yang tinggi tentu saja tidak mudah dicapai karena banyaknya faktor yang berkaitan. Secara garis besar faktorfaktor tersebut dibagi atas dua yaitu faktor eksternal dan faktor Internal. Yang dimaksud faktor eksternal adalah yang ada di luar individu, seperti faktor lingkungan, sosial (keluarga ),dan masyarakat, termasuk faktor sekolah dan faktor fasilitas belajar, sedangkan faktor Internal adalah faktor yang ada pada diri manusia seperti motivasi, minat dan sikap.

Penelitian serupa telah dilakukan oleh beberapa peneliti salah satu di antaranya adalah Titie Sukriyani (2004) yang meneliti mengenai hubungan sikap terhadap prestasi Belajar Bahasa Indonesia Siswa kelas 1 SMA Negeri 1 Bajeng kabupaten Gowa Hasil penelitian tersebut adalah menyatakan bahwa ada hubungan sikap terhadap prestasi belajar bahasa Indonesia.

Menurut Lambert (dalam Moliono dkk1991: 31- 32 ) sikap terdiri dari komponen yaitu komponen efektif, komponen kognetif, dan komponen psikomotorik. Komponen koknetif berupa kepercayaan dan komponen efektif berupa perasaan yang menyangkut emosional dan komponen psikomotorik berupa kecenderungan yang bertingkah laku dengan sikap.

\section{TINJAUAN PUSTAKA}

Membicarakan batasan pengertian sikap tidak bisa lepas dari berbagai pendapat para ahli berdasarkan sudut pandang masing masing, oleh karena itu, dalam tulisan ini penulis akan berusaha merangkum berbagai pendapat tentang pengertian sikap.

Poerwadarmita, W. J. S ( 1985 : 944 ) mengemukakan bahwa sikap adalah tingkah laku, perbuatan yang berdasarkan pada pendirian pendapat atau keyakinan.

Menurut Moelono, dkk. ( 1997 : 31 38 ) sikap adalah tindakan atau tingkah laku yang dipilih diantara sejumlah pilihan tindakan yang bisa dilakukan. Hal ini telah diselidiki sejak peralihan abad ke - 19 melalui eksperimen amggapan yang mendasarinya adalah bahwa melalui pengalaman pengalaman yang spesifik terjadi harapan harapan atau dengan kata lain hal-hal yang pernah dialami akan mempunyai suatu arti.
Menurut Roechacher ( dalam Moeliono, dkk ) bahwa sikap mempunyai pengaruh memilih dan mengemudikan kejadian- kejadian dengan sadar. Disisi lain sisi psikologi sosial, sikap adalah kecenderungan individual yang dapat ditemukan dari cara-cara berbuat dalam berhadapan dan faktor- faktor sosial

Allport berpendapat ( dalam Rasyid : 1992 : 58 ) yang diikuti oleh Suharni ( 2004 : 13 ) mengemukakan bahwa sikap adalah mental dan pernyataan syarat dan kesiapan yang diatur melalui pengalaman, menggunakan petunjuk atau pengaruh dinamis reaksi seseorang terhadap setiap tujuan atau keadaan .

Sikap penilaian adalah penilaian yang dilakukan pendidik terhadap sikap dan tingkah laku anak didik didalam kelas, terutama ketika proses belajar berlangsung. dengan menggunakan alat dan skala penilaian khusus seperti skala likerst, sikap anak didik dapat dinilai.

Segala bentuk kegiatan yang dilaksanakan oleh seseoarang pada dasarnya bertujuan untuk memperoleh suatu hasil. Hasil itu diperoleh melalui upaya yang dapat menjadi pengalaman bagi yang bersangkutan.

Dalam belajar, seseorang dapat memperoleh suatu pengalaman baru sebagai hasil belajarnya. Pengalaman-pengalaman baru yang dapat diperoleh melalui proses belajar berupa pengetahuan, keterampilan serta sikap atau tindakan. Seorang guru yang mengerti dan kreatif selalu ingin agar para anak didiknya dapat memperlihatkan hasil belajar yang tinggi. Keberhasilan seorang guru dalam menunaikan tugasnya, dapat dilihat dari hasil belajar yang dicapai oleh anak didiknya. Tingkat keberhasilan itulah yang disebut prestasi.

Berbicara mengenai prestasi belajar, maka kita terpaut pada dua aspek yang tidak dapat dipisahkan antar satu dengan yang lainnya, yaitu antara prestasi dan belajar itu sendiri. Untuk memperoleh suatu pengertian yang mendasar dari prestasi belajar tersebut maka kedua aspek tersebut perlu ditelusuri pengertiannya.

Dalam kamus umum bahasa Indonesia dinyatakan prestasi adalah hasil yang telah dicapai, dilakukan, dikerjakan ( 
Poerwadarmita, 1984 : 768 ). Jadi,yang dimaksud dengan prestasi adalah hasi dari suatu pekerjaaan yang dilakukan seseorang sesuai dengan kesanggupan atau kemampuannya. Dengan kata lain, prestasi adalah hasil tertinggi yang dapat dicapai oleh seseorang atau suatu bangsa dalam suatu pekerjaan dapat dicapai melalui tahap demi tahap asal ada kemampuan dan latihan yang teratur secara berkesinambungan.

Whiteringson ( dalam Hasan, 1994 : 86 ) mengemukakan belajar adalah suatu perubahan dalam kepribadian.

Selanjutnya, pengertian belajar menurut H. Balnadi Sutadipura adal;ah sebagai berikut :

Belajar ialah mendapatkan keterampilan - keterampilan baru, arti dan penjagaan diri pribadi, termasuk mejauhkan diri dan tidak melakukan hal-hal yang tidak baik yang pernah dilakukan orang sebelumnya. Dalam arti kata yang lebih khusus lagi, mempelajari sesuatu itu biasanya diikuti dengan suatu perubahan oleh tingkath laku, berpikr atau berperasaan ( $1985: 114$ ).

Dari pengertian yang dikemukakan oleh para ahli tersebut, maka dapat disimpulkan bahwa yang dimaksud belajar ialah suatu kegiatan yang dapat membawa perubahan pada diri seseorang yang bersangkutan terutama dalam perkembangan pengetahuan, pemantapan sikap atau peningkatan keterampilan

Dalam belajar seseorang dapat menyempurnakan pola dan tingkah lakunya dan dapat membina kebiasaan- kebiasaannya, sehingga terampil menjawab tantangan zaman atau keadaan hidup secara manusiawi. Dengan kata lain, belajar adalah memiliki kemampuan berpikir dan bertindak.

Dengan demikian, setiap orang yang tidak mengikuti proses belajar akan menampakkan adanya perubahan pengetahuan, sikap atau keterampilan ke taraf yang lebih baik atau lebih tinggi dari taraf semula. Dalam hal ini taraf atau tingkat perubahan pengetahuan sikap, dan keterampilan itulah yang merupakan produk belajar.
Berdasarka pengertian prestasi dan belajar diatas dapat diperoleh pengertian tentang prestasi belajar yaitu sebagai suatu hasil yang dicapai seorang siswa setelah melakukan aktivitas belajar. Jadi, untuk mengetahui prestasi belajar siswa, terlebih dahulu diperoleh proses penilaian dan pengukuran kegiatan evaluasi : Alat evaluasi dalam pengukuran prestasi belajar adalah tes yang telah disusun dengan baik supaya hasilnya benar-benar dapat mengukur kemampuan seorang siswa. Tes yang demikian ini disebut tes standar.

Untuk memperoleh pengertian prestasi belajar secara lebih jelas lagi, maka penulis merasa perlu untuk mengemukakan pengertian prestasi belajar menurut pendapat beberapa para ahli bahasa:

a. Syamsu Mappa ( 1977 : 2 ) mengemukakan bahwa : Prestasi belajar adalah hasi yang dicapai siswa dalam bidang study tertentu dengan menggunakan tes standar sebagai alat pengukur keberhasilan belajar seseorang siswa.

b. Umar Titaraharja megemukakan : prestasi belajar adalah taraf kemampuan aktual yang bersifat terukur berupa penguasaan ilmu pengetahuan, keterampilan, sikap interes dicapai oleh siswa dari apa yang telah dipelajari disekolah, ( $1981: 31$ )

c. Rahmat Natawijaya ( $1979: 173$ ) mengemukakan:

prestasi belajar adalah hasil yang dicapai hubungannya dengan bahan yang telah dipelajari yang tampak dalam tingkah lakunya.

Berdasarkan pengertian yang dikemukakan oleh para ahli tersebut, maka dapatlah disimpulkan yang dimaksud dengan prestasi belajar adalah hasil belajar yang dicapai dari usaha atau kegiatan belajar yang dilakukan secara sadar. Hasil belajar tersebut ditandai dengan adanya suatu perubahan sikap atau tingkah laku pada diri orang yang belajar. Prestasi belajar menggunakan tolok ukur dari pelaksanaan proses belajar-mengajar. Karena proses belajar itu dapat diketahui keberhasilan seseorang dalam belajarnya. Keberhasilan seseorang guru dalam 
mengajar dapat diketahui dalam proses belajar-mengajar tersebut. Prestasi belajar yang baik dari seluruh siswa merupakan sasaran di dalam proses belajar-mengajar. Jadi prestasi belajar itu merupakan perubahan tingkah laku yang tampak pada perubahan pengetahuan, keterampilan dan sikap mental. Secara terperinci hasil-hasil belajar itu meliputi keterampilan intelektual, penguasaan pengertian-pengertian, perhitungan kognitif, keterampilan metodik, sikap mental dan kemauan prestasi belajar. Untuk menentukan tingkat keberhasilan dan penguasaan hal-hal tersebut diatas, di sekolah formal dinyatakan dalam bentuk angka dan huruf.

Setiap guru dalam mata pelajaran sebaiknya memperhatikan keadaan siswanya, apakah sudah mencapai prestasi belajar yang diharapkan ? Apakah perubahan tingkah laku mereka sudah positif atau belum ? Dan seberapa jauh hal itu tampak dalam kehidupan sehari-hari ? Bila setiap jawaban tersebut telah dijawab dengan "ya" maka guru telah berhail dalam mengajar.

\section{METODE PENELITIAN}

\section{A. Variabel dan Desain penelitian}

\section{Variabel penelitian}

Variabel adalah unsur yang diteliti dalam suatu penelitian. Penelitian dua variabel, yaitu Variabel $=\mathrm{X}$ bebas dalam penelitian ini adalah sikap siswa di kelas sedangkan variabel $=\mathrm{Y}$ terikat adalah prestasi belajar bahasa Indonesia.

\section{Desain penelitian}

Untuk mendapatkan data yang akurat,maka proses penelitian ini dirancang sedemikian rupa sehingga Hal-hal yang tidak berhubungan dengan tujuan penelitian dapat dihindari.Oleh karena itu, kegiatan penelitian ini melalui beberapa tahap pertama yaitu diadakan tinjauan kesekolah tempat penelitian untuk mengamati situasi dan kondisi sekolah tersebut termasuk waktu yaitu tahap penyusunan proposal penelian termasuk instrumen yang akan dipergunakan untuk menjaring data termasuk surat izn penelitian dari pihak terkait.

\section{B. Defenisi Oporasional Variabel}

Untuk menghindari pengertian yang keliru maka telah dijelaskan tentang Definisi operasional variabel sebagai berikut:

Sikap adalah penyatuan siswa dalam mempelajari materi yang diberikan.sedangkan prestasi adalah nilai yang mampu dicapai oleh siswa setela diadakan evaluasi pada bidang studi bahasa Indonesia.

\section{Populasi dan Sampel}

1. Populasi

Populasi adalah objek yang menjadi sasaran penelitian. Winardi, (1979:230) mengemukakan bahwa:" Populasi adalah kolompok semua elemen yang mengandung keuntungan yang diperlukan guna menjelaskan sebuah problem, atau untuk alasan lain".

Populasi dalam penelitian ini adalah semua siswa kelas II SMP Negeri 3 Batu leppa kecamatan sinjai selatan kabupaten sinjai tahun ajaran 2007/2008 sebanyak 160 orang. Untuk Lebih jelasnya dapat dilihat pada tabel berikut:

Tabel 1. Keadaan Populasi

\begin{tabular}{|c|c|c|c|c|}
\hline \multirow[t]{2}{*}{ No } & \multirow[t]{2}{*}{ Kelas } & \multicolumn{2}{|c|}{ Jenis Kelamin } & \multirow[t]{2}{*}{ Jumlah } \\
\hline & & $\begin{array}{l}\text { Laki- } \\
\text { Laki }\end{array}$ & Perempuan & \\
\hline 1 & $11_{1}$ & 21 & 20 & 41 \\
\hline 2 & $11_{2}$ & 19 & 21 & 40 \\
\hline 3 & $11_{3}$ & 20 & 20 & 40 \\
\hline 4 & $11_{4}$ & 19 & 20 & 39 \\
\hline \multicolumn{2}{|c|}{ Total } & 79 & 81 & 160 \\
\hline
\end{tabular}

Sumber Data : $\quad$ Papan Potensi SMP Negari 3 Batu Leppa Kecamatan Sinjai Selatan Kabupaten. SinjaiTahun Pelajaran 2007/2008

\section{Sampel}

Dalam penelitian ini tidak semua populasi dapat deteliti mengingat terbatasnya waktu tenaga dan biaya yang tersedia untuk melaksanakan penelitian ini. Oleh kerena itu 
dalam penelitian ini dilakukan penarikan sampel.

Teknik yang digunakan dalam penarikan sampel penelitian ini adalah teknik random acak dengan mengambil $45 \%$ dari jumlah populasi.

Untuk lebih jelasnya dapat dilihat pada tabel berikut :

Tabel 2. Keadaan Sampel

\begin{tabular}{ccccc}
\hline No & Kelas & \multicolumn{2}{c}{ Jenis Kelamin } & Jumlah \\
\cline { 3 - 4 } & & $\begin{array}{c}\text { Laki- } \\
\text { Laki }\end{array}$ & Perempuan & \\
& & 10 & 8 & 18 \\
1 & $11_{1}$ & 10 & 11 & 18 \\
2 & $11_{2}$ & 7 & 6 & 18 \\
3 & $11_{3}$ & 12 & 9 & 18 \\
4 & $11_{4}$ & 9 & 34 & 72 \\
\hline \multicolumn{2}{l}{ Total } & 39 & 34
\end{tabular}

Sumber data : Papan Potensi SMP Negeri 3

Batu Leppa Kecamatan

Sinjai Selatan Kabupaten

Sinjai Tahun pelajaran 2007/ 2008

\section{Teknik Pengumpulan Data}

Data dalam penelitian ini diperoleh melalui teknik angket dan dokumentasi.

1. Angket

Teknik angket dalam penelitian ini digunakan untuk mengukur hubungan antara sikap dalam pembelajaran bahasa Indonesia siswa kelas II SMP Negeri 3 Batu Leppa Kecamatan Sinjai Kabupaten Sinjai. Angket tersebut sebanyak 10 nomor. Angket ini terdiri dari option a, b, c, dan d dengan menggunakan skala Lickert $(4,3,2$ dan 1$)$

\section{Dokumentasi}

Teknik dokumentasi dalam penelitian ini di gunakan untuk memperoleh data tentang prestasi belajar bidang studi bahasa Indonesia yang di ambil dari yang ada dalam buku rapor siswa pada semester I Tahun Pelajaran 2007/2008.

\section{E. Teknik Analisis Data}

Data yang diperoleh dianalisis dengan menggunakan teknik analisis korelasi produk momen dengan rumus sebagai berikut:

$$
\begin{aligned}
& \sum \chi \gamma-\frac{\left(\sum \chi\right)\left(\sum y\right)}{\mathrm{N}} \\
& \sqrt{\{\chi \gamma=} \frac{\left.\left.\sqrt{\left\{\sum \chi^{2}-\frac{\left(\sum \chi\right)^{2}}{\mathrm{~N}}\right\}}\right\} \sum \gamma^{2 \frac{\left(\sum \gamma\right)^{2}}{\mathrm{~N}}}\right)}{}
\end{aligned}
$$

(Sutrisno Hadi,200:122)

Keterangan:

$\sum \chi \gamma \quad=$ Koefisien

korelasi antara $\chi$ dan $y$

$\mathrm{N} \quad=$ Jumlah

sampel

$\sum \quad=$ Sigma

(pemjumlahan)

$\sum \chi \quad=$ Sikap

dalam pembelajaran bahasa indonesia

$$
\sum y \quad=\text { prestasi }
$$

belajar bidang studi bahasa indonesia

$$
\sum \chi^{2}=\text { Kuadrat }
$$

dari variabel $\chi$

$$
\sum y^{2} \quad=\text { Kuadrat }
$$

dari variabel $y$

\section{HASIL DAN PEMBAHASAN}

A. Penyajian Hasil Penelitian

Data penelitian ini adalah sikap sebagai variabel $\mathrm{x}$ dan prestasi belajar bahasa Indonesia siswa kelas II SMP Negeri 3 Batu Leppa kecamatan Sinjai Selatan Kabupaten Sinjai sebagai variabel $Y$. Data variabel $X$ diperoleh dari skor angket yang diberikan kepada responden, sedangkan data variabel $\mathrm{Y}$ diperoleh dari nilai prestasi belajar bahasa Indonesia yang ada dalam buku rapor siswa pada semester dua tahun ajaran 2007/2008

Tabel 3. Distribusi Sikap Terhadap Prestasi Belajar Bahasa Indonesia

Siswa Kelas II SMP Negeri 3 Batu Leppa Kecamatan Sinjai Selatan Kabupaten Sinjai

\begin{tabular}{cccc}
\hline No & $\begin{array}{c}\text { Kode } \\
\text { Sampel }\end{array}$ & $\begin{array}{c}\text { Skor } \\
\text { Angket }\end{array}$ & $\begin{array}{c}\text { Prestasi } \\
\text { Belajar }\end{array}$ \\
\hline 1 & $\mathbf{2}$ & $\mathbf{3}$ & $\mathbf{4}$ \\
\hline
\end{tabular}




\begin{tabular}{|c|c|c|c|}
\hline 1 & 001 & 34 & 8 \\
\hline 2 & 002 & 38 & 6 \\
\hline 3 & 003 & 36 & 6 \\
\hline 4 & 004 & 32 & 7 \\
\hline 5 & 005 & 40 & 8 \\
\hline 6 & 006 & 39 & 6 \\
\hline 7 & 007 & 36 & 6 \\
\hline 8 & 008 & 36 & 6 \\
\hline 9 & 009 & 40 & 8 \\
\hline 10 & 010 & 38 & 8 \\
\hline 11 & 011 & 34 & 6 \\
\hline 12 & 012 & 36 & 7 \\
\hline 13 & 013 & 38 & 8 \\
\hline 14 & 014 & 39 & 8 \\
\hline 15 & 015 & 40 & 8 \\
\hline 16 & 016 & 32 & 6 \\
\hline 17 & 017 & 34 & 7 \\
\hline 18 & 018 & 37 & 6 \\
\hline 19 & 019 & 36 & 6 \\
\hline 20 & 020 & 38 & 8 \\
\hline 21 & 021 & 36 & 6 \\
\hline 22 & 022 & 38 & 8 \\
\hline 23 & 023 & 40 & 8 \\
\hline 24 & 024 & 37 & 7 \\
\hline 25 & 025 & 36 & 6 \\
\hline 26 & 026 & 38 & 8 \\
\hline 27 & 027 & 34 & 6 \\
\hline 28 & 028 & 39 & 8 \\
\hline 29 & 029 & 32 & 6 \\
\hline 30 & 030 & 40 & 8 \\
\hline 31 & 031 & 36 & 6 \\
\hline 32 & 032 & 38 & 8 \\
\hline 33 & 033 & 38 & 8 \\
\hline 34 & 034 & 32 & 6 \\
\hline 35 & 035 & 36 & 6 \\
\hline 36 & 036 & 36 & 6 \\
\hline 37 & 037 & 40 & 8 \\
\hline 38 & 038 & 40 & 8 \\
\hline 39 & 039 & 37 & 6 \\
\hline 40 & 040 & 34 & 7 \\
\hline 41 & 041 & 38 & 6 \\
\hline 42 & 042 & 32 & 8 \\
\hline 43 & 043 & 36 & 8 \\
\hline 44 & 044 & 6 & 6 \\
\hline 45 & 045 & 38 & 6 \\
\hline 46 & 046 & 36 & 6 \\
\hline 47 & 047 & 39 & 8 \\
\hline 48 & 048 & 40 & 8 \\
\hline 49 & $\begin{array}{l}049 \\
\end{array}$ & 37 & 7 \\
\hline 50 & 050 & 34 & 6 \\
\hline
\end{tabular}

\begin{tabular}{llll}
\hline 51 & 051 & 35 & 8 \\
\hline 52 & 052 & 32 & 8 \\
\hline 53 & 053 & 36 & 6 \\
\hline 54 & 054 & 39 & 6 \\
\hline 55 & 055 & 36 & 6 \\
\hline 56 & 056 & 40 & 7 \\
\hline 57 & 057 & 34 & 6 \\
\hline 58 & 058 & 32 & 6 \\
\hline 59 & 059 & 34 & 8 \\
\hline 60 & 060 & 40 & 8 \\
\hline 61 & 061 & 35 & 8 \\
\hline 62 & 062 & 38 & 7 \\
\hline 63 & 063 & 38 & 7 \\
\hline 64 & 064 & 37 & 8 \\
\hline 65 & 065 & 39 & 7 \\
\hline 66 & 066 & 36 & 6 \\
\hline 67 & 067 & 34 & 6 \\
\hline 68 & 068 & 30 & 6 \\
\hline 69 & 069 & 40 & 7 \\
\hline 70 & 070 & 36 & 6 \\
\hline 71 & 071 & 40 & 8 \\
\hline 72 & 072 & 40 & 8 \\
\hline
\end{tabular}

Pada data tabel 3. di atas tindak lanjuti guna mencari koofesien korelasi antara sikap sebagai varibel $\mathrm{x}$ terhadap prestasi belajar bahasa indonesia siswa kelas II SMP Negeri 3 Batu Leppa Kecamatan Sinjai Selatan Kabupaten Sinjai (variabel Y).

Tabel 4. Tebel Kerja dari Tabel 3.

\begin{tabular}{cccccc}
\hline $\mathbf{N O}$ & $\mathbf{X}$ & $\mathbf{Y}$ & $\mathbf{X}^{\mathbf{2}}$ & $\mathbf{Y}^{\mathbf{2}}$ & $\mathbf{X Y}$ \\
\hline 1 & 34 & 8 & 1156 & 64 & 272 \\
\hline 2 & 38 & 6 & 1444 & 36 & 228 \\
\hline 3 & 36 & 6 & 1296 & 36 & 216 \\
\hline 4 & 32 & 7 & 1024 & 49 & 224 \\
\hline 5 & 40 & 8 & 1600 & 64 & 320 \\
\hline 6 & 39 & 6 & 1521 & 36 & 234 \\
\hline 7 & 36 & 6 & 1296 & 36 & 216 \\
\hline 8 & 36 & 6 & 1296 & 36 & 216 \\
\hline 9 & 40 & 8 & 1600 & 64 & 320 \\
\hline 10 & 38 & 8 & 1444 & 64 & 304 \\
\hline 11 & 34 & 6 & 1156 & 36 & 204 \\
\hline 12 & 36 & 7 & 1296 & 49 & 525 \\
\hline 13 & 38 & 8 & 1444 & 64 & 304 \\
\hline 14 & 39 & 8 & 1521 & 64 & 312 \\
\hline 15 & 40 & 8 & 1600 & 64 & 320 \\
\hline 16 & 32 & 6 & 1024 & 36 & 192 \\
\hline 17 & 34 & 7 & 1156 & 49 & 238 \\
\hline 18 & 37 & 6 & 1369 & 36 & 222 \\
\hline 19 & 36 & 6 & 1296 & 36 & 216 \\
\hline 20 & 38 & 8 & 1444 & 64 & 304 \\
\hline
\end{tabular}




\begin{tabular}{cccccc}
\hline 21 & 36 & 6 & 1296 & 36 & 216 \\
\hline 22 & 38 & 8 & 1444 & 64 & 304 \\
\hline 23 & 40 & 8 & 1600 & 64 & 320 \\
\hline 24 & 37 & 7 & 1369 & 49 & 259 \\
\hline 25 & 36 & 6 & 1296 & 36 & 216 \\
\hline 26 & 38 & 8 & 1444 & 64 & 304 \\
\hline 27 & 34 & 6 & 1156 & 36 & 204 \\
\hline 28 & 39 & 8 & 1521 & 64 & 312 \\
\hline 29 & 32 & 6 & 1024 & 36 & 192 \\
\hline 30 & 40 & 8 & 1600 & 64 & 320 \\
\hline 31 & 36 & 6 & 1296 & 36 & 216 \\
\hline 32 & 38 & 8 & 1444 & 64 & 304 \\
\hline 33 & 38 & 8 & 1444 & 64 & 304 \\
\hline 34 & 32 & 6 & 1024 & 36 & 192 \\
\hline 35 & 36 & 6 & 1296 & 36 & 216 \\
\hline 36 & 36 & 6 & 1296 & 36 & 216 \\
\hline 37 & 40 & 8 & 1600 & 64 & 320 \\
\hline 38 & 40 & 8 & 1600 & 64 & 320 \\
\hline 39 & 37 & 6 & 1369 & 36 & 222 \\
\hline 40 & 34 & 7 & 1156 & 49 & 238 \\
\hline 41 & 38 & 6 & 1444 & 36 & 228 \\
\hline 42 & 32 & 8 & 1024 & 64 & 256 \\
\hline 43 & 36 & 8 & 1296 & 64 & 288 \\
\hline 44 & 36 & 6 & 1296 & 36 & 266 \\
\hline 45 & 38 & 6 & 1444 & 36 & 228 \\
\hline 46 & 36 & 6 & 1296 & 36 & 216 \\
\hline 47 & 39 & 8 & 1521 & 63 & 312 \\
\hline 48 & 40 & 8 & 1600 & 6 & 320 \\
\hline 49 & 37 & 7 & 1369 & 49 & 259 \\
\hline 50 & 34 & 6 & 1156 & 36 & 204 \\
\hline 51 & 35 & 8 & 1225 & 46 & 280 \\
\hline 52 & 32 & 8 & 1024 & 64 & 256 \\
\hline & & & & & \\
\hline 35
\end{tabular}

\begin{tabular}{cccccc}
\hline 53 & 36 & 6 & 1296 & 36 & 216 \\
\hline 54 & 39 & 6 & 1521 & 36 & 234 \\
\hline 55 & 36 & 6 & 1296 & 36 & 216 \\
\hline 56 & 40 & 7 & 1600 & 49 & 280 \\
\hline 57 & 34 & 6 & 1156 & 36 & 204 \\
\hline 58 & 32 & 6 & 1024 & 36 & 192 \\
\hline 59 & 34 & 8 & 1156 & 64 & 272 \\
\hline 60 & 40 & 8 & 1600 & 64 & 320 \\
\hline 61 & 35 & 8 & 1225 & 64 & 280 \\
\hline 62 & 38 & 7 & 1444 & 49 & 266 \\
\hline 63 & 38 & 7 & 1444 & 49 & 304 \\
\hline 64 & 37 & 8 & 1369 & 64 & 296 \\
\hline 65 & 39 & 7 & 1521 & 49 & 273 \\
\hline 66 & 36 & 6 & 1296 & 36 & 216 \\
\hline 67 & 34 & 6 & 1156 & 36 & 704 \\
\hline 68 & 30 & 6 & 900 & 36 & 180 \\
\hline 69 & 40 & 7 & 1600 & 49 & 280 \\
\hline 70 & 36 & 6 & 1296 & 36 & 216 \\
\hline 71 & 40 & 8 & 1600 & 64 & 320 \\
\hline 72 & 40 & 8 & 1600 & 64 & 320 \\
\hline Jumla & $\mathrm{X}=$ & $\mathrm{Y}$ & $\mathrm{X}^{2}=$ & $\mathrm{Y}^{2}=$ & $\mathrm{XY}=$ \\
$\mathrm{h}$ & 263 & $=$ & 4692 & 386 & 1853 \\
& 7 & 50 & 0 & 2 & 7 \\
& & 2 & & & \\
\hline & $\mathrm{B} g a r k n$ &
\end{tabular}

Berdasarkan hasil perhitungan pada tabel 4 di atas diketahui sebagai berikut :

$$
\begin{aligned}
\sum x y & =18537 \\
N & =72 \\
\sum x & =2637 \\
\sum y & =502 \\
\sum x^{2} & =97053 \\
\sum y^{2} & =3862
\end{aligned}
$$


Tabel 5

Harga kritik Dari Product Moment

\begin{tabular}{|c|c|c|c|c|c|c|c|c|}
\hline \multirow[t]{2}{*}{$\mathrm{N}$} & $\overline{\text { interval }}$ & kepercayaan & \multirow[t]{2}{*}{$\mathrm{N}$} & interval & Kepercayaan & \multirow[t]{2}{*}{$\mathrm{N}$} & $\begin{array}{l}\text { Interval } \\
\end{array}$ & Kepercayaan \\
\hline & $95 \%$ & $99 \%$ & & $95 \%$ & $99 \%$ & & $95 \%$ & $99 \%$ \\
\hline (1) & (2) & (3) & (1) & (2) & (3) & (1) & (2) & (3) \\
\hline 3 & 0,997 & 0,999 & 26 & 0,388 & 0,496 & 55 & 0,266 & 0,345 \\
\hline 4 & 0,950 & 0,990 & 27 & 0,381 & 0,487 & 60 & 0,254 & 0,330 \\
\hline 5 & 0,878 & 0,959 & 28 & 0,374 & 0,478 & 65 & 0,244 & 0,317 \\
\hline 6 & 0,811 & 0,870 & 29 & 0,367 & 0,470 & 70 & 0,235 & 0,306 \\
\hline 7 & 0,764 & 0,874 & 30 & 0,361 & 0,463 & 75 & 0,227 & 0,296 \\
\hline 8 & 0,707 & 0,874 & 31 & 0,335 & 0,456 & 80 & 0,220 & 0,286 \\
\hline$\overline{9}$ & 0,666 & 0,798 & 32 & 0,349 & $\overline{0,449}$ & 85 & 0,213 & 0,278 \\
\hline$\overline{10}$ & 0,632 & 0,765 & 33 & 0,344 & 0,442 & 90 & 0,207 & 0,270 \\
\hline 11 & 0,602 & 0,735 & 34 & 0,339 & 0,436 & 95 & 0,202 & 0,263 \\
\hline$\overline{12}$ & 0,576 & 0,708 & 35 & 0,335 & 0,430 & 100 & 0,192 & 0,256 \\
\hline 13 & 0,553 & 0.784 & 36 & 0,329 & 0,424 & 125 & 0,176 & 0,230 \\
\hline$\overline{14}$ & 0,532 & 0,761 & 37 & 0,325 & 0,418 & 150 & 0,159 & 0,210 \\
\hline 15 & 0,514 & 0,641 & 3 & 0,320 & 0,413 & 175 & 0,148 & 0,194 \\
\hline$\overline{16}$ & 0,497 & 0,623 & 39 & 0,316 & 0,408 & 200 & 0,113 & 0,181 \\
\hline 17 & 0,842 & 0,606 & 40 & 0,312 & 0,403 & 300 & 0,113 & 0,148 \\
\hline$\overline{18}$ & 0,462 & 0,590 & 41 & 0,308 & 0,396 & 400 & 0,098 & 0,128 \\
\hline 19 & 0,456 & 0,575 & 42 & 0,304 & 0,393 & 500 & 0,088 & 0,115 \\
\hline 20 & 0,444 & 0,561 & 43 & 0,301 & 0,389 & 600 & 0,080 & 0,185 \\
\hline 21 & 0,433 & 0,549 & 44 & 0,297 & 0,384 & 700 & 0,074 & 0,297 \\
\hline 22 & 0,423 & 0,573 & 45 & 0,294 & 0,380 & 800 & 0,070 & 0,091 \\
\hline 23 & 0,413 & 0,56 & 46 & 0,297 & 0,276 & 900 & 0,065 & 0,086 \\
\hline 24 & 0,404 & 0,515 & 47 & 0,288 & 0,372 & 1000 & 0,062 & 0,81 \\
\hline 25 & 0,396 & 0,505 & 48 & 0,284 & 0,3666 & & & \\
\hline & & & 49 & 0,281 & 0,364 & & & \\
\hline
\end{tabular}


Selanjutnya dapat dapat dicari koofesien korelasi antara variabel $\mathrm{x}$ dan $\mathrm{y}$ dengan menggunakan rumus Korelasi Product Moment dengan rumus sebagai berikut:

$$
\begin{aligned}
& r x y=\frac{\sum x y-\frac{\left(\sum x\right)\left(\sum y\right)}{N}}{\sqrt{\left\{x^{2}-\frac{\left(\sum x\right)^{2}}{N}\right\}\left\{\sum y^{2}-\frac{\left(\sum y\right)^{2}}{N}\right\}}} \\
& =\frac{18537-\frac{(2637)(502)}{72}}{\sqrt{\left\{97053-\frac{(2637)^{2}}{72}\right\}\left\{3862-\frac{(502)^{2}}{72}\right\}}} \\
& =\frac{18537-\frac{(1323774)}{72}}{\sqrt{\left\{97053-\frac{6953769}{72}\right\}\left\{3862-\frac{252004}{72}\right\}}} \\
& =\frac{18537-18385,75}{\sqrt{\{97053-96580,1,\{3862-3500,05\}}} \\
& =\frac{151,25}{\sqrt{\{472,9\}\{61,95\}}} \\
& =\frac{151,25}{\sqrt{29296,15}} \\
& =\frac{151,25}{171,08} \\
& =0,884
\end{aligned}
$$

Berdasarkan perhitungan akhir diatas diketahui nilai koefesian antara sikap dan prestasi belajar Bahasa indonesia siswa kelas II SMP Negeri 3 Batu Leppa Kecamatan sinjai selatan kabupaten Sinjai.

\section{B. Pembahasan hasil penelitian}

Berdasarkan hasil analisis data diatas, diperoleh nilai $\mathrm{r}$ - hitung sebesar 0,884 . untuk mengetahui menguji hipotesis penelitian maka nilai $r$ - hitung dibandingkan dengan nilai $\mathrm{r}$ - tabel pada taraf kepercayaan $5 \%$. Kriteria pengujian hipotesis adalah sebagai berikut:
1. Apabila nilai $\mathrm{r}$ - hitung lebih besar dari pada nilai $r$-tabel, maka hipotesis diterima.

2. Apabila nilai $\mathrm{r}-$ hitung lebih kecil dari nilai $r$ - tabel,maka hipotesis ditolak.

3. Nilai $\mathrm{r}$ - tabel yang digunakan sebagi pembanding diketahui dengan cara mencari nilai yang berada pada titik pertemuan antara taraf kepercayaan 5\%dan $\mathrm{N}: 72$.

Karena tidak ada N: 72 dalam tabel nilai-nilai $\mathrm{r}$ product moment,maka mengambil $\mathrm{N}$ yang mendekati yaitu 75 adalah 0,227 atas dasar taraf analisis data lebih tinggi atau lebih besar dari pada nilai $r$ - tabel maka berdasarkan kriteria pengujian hipotesis diatas, maka hipotesis diterima.

"Ada hubungan sikap terhadap prestasi belajar Bahasa Indonesia siswa kelas

II SMP Negeri 3 Batu Leppa kecamatan sinjai selatan kabupaten sinjai,"

\section{KESIMPULAN}

Berdasarkan pembahasan hasil penelitian, penulis menyimpulkan sebagi berikut:

Ada hubungan sikap terhadap prestasi belajar Bahasa indonesia siswa dengan koefisien 5\% Nilai $\mathrm{r}$ - hitung yang diperoleh yaitu 0,844 lebih besar dari pada Nilai $\mathrm{r}$ - tabel yaitu 0,227 atas dasar tarif siknifikan 5\% Dengan demikian hipotesis yang diajukan dalam penelitian ini dinyatakan telah diterima,diterimanya hipotesis peneliti ini merupakan suatu indekasi pada pengaruh yang signifikan sikaf belajar terhadap peningkatanprestasi belajar Bahasa indonesia siswa kelas II SMP Negeri 3 Batu Leppa kecamatan sinjai selatan kabupaten sinjai.

\section{DAFTAR PUSTAKA}

Abimanyu, Soli. 1977. Diagnostik Kesulitan Belajar. Tanpa nama penerbit dan tempat terbit. 
Ali, M. 1985. Penelitian Pendidikan Prosedur dan Strategi. Bandung : Angkasa.

Arikunto, S. 1998. Prosedur Penelitian. Edisi Revisi IV, Jakarta : PT. Rineka Cipta.

Dalyono M, 2001. Psikologi Pendidikan. Jakarta. PT. Rineka Cipta.

Hadi, Sutrisno, 1984. Statistik II. Yogyakarta Fakultas Psikologi UGM.

Hasan, H. Chalijah, 1994. Dimensi-dimensi Psikologi Pendidikan. Surabaya : Al-Ikhlas.

Kridalaksa, H. 1984. Kamus Linguistik. Jakarta. Departemen Pendidikan dan Kebudayaan.

Mappa, Syamsu, 1977. Psikologi Pendidikan. Ujung Pandang : FKIP-IKIP.

Moeliono, dkk 1997. Kamus Besar Bahasa Indonesia. Jakarta : Departemen Pendidikan dan Kebudayaan.

Munandar, U, 1966. Psikologi Belajar. Jakarta : PT. Raja Gafindo Persada.

Natawijaya, Rahmat, 1979. Dasar-Dasar Proses Belajar Mengajar. Jakarta : Gramedia.

Poerbakawatja dan Harahap H. A.M. 1991. Ensiklopedi Pendidikan. Jakarta : Gramedia.

Poerwadarminta, W. J. S. 1985. Kamus Umum Bahasa Indonesia. Jakarta : Departemen Pendidikan dan Kebudayaan.

Slamento. 1987. Belajar dan Faktor-faktor yang Mempengaruhi. Jakarta : Bina Aksara.

Suardiman. 1988. Psikologi Konseling. Yogyakarta : Fakultas Psikologi UGM.

Soedjana. Nana dkk. 1989. Cara Belajar Siswa Aktif dalam Proses
Belajar Mengajar. Bandung : Pioner Jaya.

Sukardi, Ketut. 1982. Tes Dalam Konseling Karier. Surabaya : Usaha Nasional.

Sutadipura, H. Balnadi. 1985. Belajar dan pembelajaran. Jakarta : Gramedia

Titaraharja Umar. 1981. Psikoogi Umum. Jakarta : PT. Rineka Cipta.

Yolius. 1980. Kamus Bahasa Indonesia. Tanpa Penerbit. 